ARTIKEL

Filsafat Politik Nurcholish Madjid

Muhammad Saleh Tajuddin

Kedaulatan Rakyat dalam Pemikiran Filsafat

Politik Montesquieu

Fajrul Ilmy Darussalam \& Andi Batara Indra

$189-204$

Politik Multikulturalisme: Sebuah Gerakan Keadilan

dan Kesetaraan

Muhaemin Latif

$205-229$

Kompetisi, Kompromi dan Coalition Agreement: Berebut

Kursi Wakil Gubernur DKI Jakarta di Tengah

Kontestasi Pemilihan Presiden 2019

Mahpudin \& Fransisca Mega Lestari

$230-259$

Kegagalan Keterlibatan Politik: Dari Kesenjangan Digital

Menuju Kesenjangan Demokrasi

Fairuz Arta Abhipraya \& Bambang Eka Cahya Widodo

Mobilisasi Massa Kemenangan Kolom Kosong Pada Pemilihan Walikota Makassar Tahun 2018

Gustiana Kambo

Kinerja Komisi Pemilihan Umum Kota Makassar dalam

Melindungi Hak Pilih Warga di Tengah

Pandemi COVID-19

Dyahwanti Sulistyowati, Muhammad, Sukri \& Ariana

Isu Pemekaran Wilayah Sebagai Komoditas Politik Dalam Masyarakat

To Pulo di Kepulauan Selayar

Dwi Indriani \& Sudarmono

Penanganan Konflik Melalui Keamanan di Kalimantan Barat 


\title{
ISU PEMEKARAN WILAYAH SEBAGAI KOMODITAS POLITIK DALAM MASYARAKAT TO PULO DI KEPULAUAN SELAYAR
}

\author{
Dwi Indriani ${ }^{1}$ \& Sudarmono $^{2}$ \\ Program Studi Politik Pemerintahan FPP IPDN ${ }^{1}$ \\ Program Studi Pembangun Ekonomi dan Pemberdayaan Masyarakat FPP IPDN ${ }^{2}$ \\ Email: dwiindriani631@gmail.com ${ }^{1}$, sudarmono@ipdn.ac.id ${ }^{2}$
}

\begin{abstract}
Abstrak
Desentralisasi penyelenggaraan pemerintahan daerah diharapkan mampu mendorong kesejahteraan sosial ekonomi masyarakat. Salah satu peluang yang bisa dilakukan adalah dengan membentuk DOB melalui redistricting. Dengan memprovokasi isu redistricting, elit lokal kemudian menjadikan isu ini sebagai komoditas politik untuk memperluas popularitas politik dan meningkatkan elektabilitas mereka. Tulisan ini bertujuan untuk 1) menemukenali faktor yang melatarbelakangi tuntutan pembentukan DOB dengan meredistribusi pulau-pulau tertentu di Kabupaten Kepulauan Selayar; 2) mendeskripsikan peran elit politik dalam upaya pemekaran Kabupaten Kepulauan Selayar; dan 3) menganalisis dinamika terkini terkait isu redistriksi wilayah Kabupaten Kepulauan Selayar. Dengan menggunakan pendekatan kualitatif ditemukan bahwa keadaan geografis, ketimpangan sosial ekonomi masyarakat adat setempat dan perbedaan identitas budaya menjadi salah satu faktor yang mendorong tuntutan pembentukan wilayah otonom baru. Juga ditemukan bahwa elit lokal memainkan peran penting di balik agenda redistricting karena alasan tertentu, terutama untuk mempertahankan kekuasaan dan otoritas mereka. Namun, wilayah baru tidak dapat didirikan, tetapi masalah tersebut tetap diartikulasikan.
\end{abstract}

Kata Kunci:

Pemekaran Wilayah, Desentralisasi, Elit, Ketimpangan Pembangunan, Kepualaun Selayar

\begin{abstract}
The decentralization of a local government administration is expected to promote the socioeconomic prosperity of its community. One of the opportunities that could be done is by establishing a new autonomous region through redistricting. By provoking the issue of redistricting, local elites bring this issue to be a political commodity to expand their political popularity and increase their electability. This article aims to 1) identify the factors behind the demands for the establishing a new autonomous region by redistricting certain islands of the Kepulauan Selayar Regency; 2) describe the role of elites in the effort to expand the Regency of Kepulauan Selayar; and 3) analyze the current dynamics regarding the issue of the territorial redistriction of the Kepulauan Selayar Regency. By using a qualitative approach, it was found that geographical circumstances, socioeconomic inequality of local indigenous people and differences of cultural identity were the factors behind the demand of establishing a new autonomous territory. It is also found that local elites played a significant role behind the redistricting agenda for some reason,
\end{abstract}


particularly to sustain their power and authority. Even though the new territory is unable to be established, the issue is remained articulate.

\section{Keywords:}

Redistricting, Decentralization, Elite, Uneven Development, Kepulauan Selayar

\section{Pendahuluan}

Artikel ini bertujuan untuk menganalisis dinamika kontestasi politik lokal yang memanfaatkan isu pemekaran wilayah sebagai sebuah komoditas politik untuk meraih keuntungan berupa perolehan suara di wilayah-wilayah yang "akan dimekarkan". Geliat pemekaran wilayah merupakan refleksi desentralisasi yang diimplementasikan untuk mengatasi kegagalan sentralisasi di masa Orde Baru. Pada masa itu, sistem politik yang dijalankan dirasakan sangat otoriter, sehingga konsentrasi sumber daya telah dieksploitasi serta dikuasai sepenuhnya oleh kroni pemerintah pusat. Hal ini tidak terlepas oleh kewenangan yang sentralistik tanpa adanya upaya untuk mendelegasikan kewenangan tersebut kepada pemerintah daerah.

Lahirnya kebijakan desentralisasi melalui penetapan UU No. 22/1999 tentang Pemerintahan Daerah telah dimaknai sebuah harapan baru dalam menyelesaikan carut marut urusan pelimpahan kewenangan serta diharapkan menjadi titik terang dari permasalahan lokal bangsa Indonesia. Desentralisasi menekankan pentingnya pemindahan kekuasaan yang tidak semata-mata hanya bersifat administratif, tetapi juga termasuk proses perencanaan, pembuatan keputusan dan juga pertanggungjawaban kewenangan. ${ }^{1}$

Salah satu bagian yang diamanatkan dalam otonomi daerah ialah aturan mengenai kemungkinan dilakukannya pemekaran daerah (redistricting). Pemekaran daerah secara umum diartikan sebagai pembentukan teritorial administratif yang baru, baik pada level provinsi maupun pada level pemerintahan kabupaten/kota yang merupakan hasil pemisahan dari daerah induk. Pemekaran daerah merupakan bentuk usaha pemerintah dalam mewujudkan distibusi hasil pembangunan serta pemerataan kesempatan untuk meningkatkan derajat sosial ekonomi masyarakat. Pada saat yang bersamaan pula, eksploitasi sumber daya juga dapat dihindari oleh karena pengawasan

${ }^{1}$ Emily Edmonds-Poli \&Eduardo J. Gómez, "The Politics of Decentralization and Municipal Autonomy in Mexico and India" dalam Paper dipresentasikan pada the Annual Meeting of the American Political Science Association, San Francisco, 29 Agustus-2 September (2001). 
dari pemerintah semakin dekat. Oleh karena itu, pemerintah menetapkan Peraturan Pemerintah No. $129 / 2000^{2}$ yang memberikan landasan serta kriteria pembentukan daerah otonomi yang baru secara lebih ketat.

Sebelum era reformasi sampai tahun 1998, wilayah Indonesia dibagi ke dalam 27 provinsi. Namun, dampak dari hadirnya desentralisasi, perkembangan aspirasi masyarakat mengenai demokratisasi dan pemekaran menjadi luas dan tidak terkendali. Sehingga saat ini, berdasarkan data Kementerian Dalam Negeri Republik Indonesia, wilayah Indonesia terbagi menjadi 34 provinsi dengan total 416 kabupaten dan 98 kota mengalami pemekaran. ${ }^{3}$

Studi-studi sebelumnya mengungkapkan bahwa beberapa alasan yang menyebabkan munculnya tuntutan pemekaran daerah. Salah satu alasan yang paling populer yang digunakan dalam memekarkan suatu daerah adalah kebutuhan untuk pemerataan pembangunan sosial dan ekonomi. ${ }^{4}$ Contohnya, kasus pemekaran Minahasa Utara di Sulawesi Utara. Sementara dalam kasus ini, pemekaran wilayah dijadikan sebagai isu politik untuk menguatkan eksistensi To Pulo sebagai sebuah entitas sosial dan budaya tersendiri, yang selama ini dirasakan selalu menjadi subordinat dari masyarakat Kabupaten Kepulauan Selayar secara umum.

Selain faktor ekonomi, kondisi geografis dengan wilayah yang sangat luas menjadi alasan lainnya yang kerapkali melatarbelakangi tuntutan pemekaran di Indonesia. Infrastruktur yang tidak memadai membuat proses delivery pelayanan publik banyak tidak menyentuh masyarakat kelas bawah, khususnya masyarakat yang menetap di kawasan yang terpisah jauh dari pusat pertumbuhan ekonomi. Alhasil, mereka mendapatkan pelayanan yang kualitasnya berbeda dengan masyarakat yang berada dekat dengan pusat-pusat pertumbuhan ekonomi dan pembangunan.

Faktor perbedaan perspektif dalam hal identitas budaya juga menjadi perkara yang sering dikemukakan. Tuntutan pemekaran mengemuka oleh sebab perbedaan persepsi dalam memaknai identitas mereka. Hal ini dapat berimplikasi kepada

\footnotetext{
${ }^{2}$ Pemerintah RI, "Peraturan Pemerintah No. 129 Tahun 2000 tentang Persyaratan Pembentukan Dan Kriteria Pemekaran, Penghapusan, Dan Penggabungan Daerah" dalam https://peraturan.bpk.go.id/Home/Details/53948/pp-no-129-tahun-2000 diakses 1 Februari 2021.

${ }^{3}$ Kemendagri, "Wilayah Indonesia Pasca Mengalami Pemekaran" dalam www.kemendagri.go.id. diakses 28 Maret 2021

${ }^{4}$ Bhenyamin Hoessein, "Penyempurnaan UU No.22 Tahun 1999 Menurut Konsepsi Ootonomi Daerah Hasil Amandemen UUD 1945" dalam Makalah Untuk Seminar "Pembangunan Hukum Nasional VIII" yang diselnggarakan oleh BPHN Departemen Kehakiman dan HAM , Denpasar, 14-18 Juli (2003).
} 
munculnya konflik-konflik horizontal yang berkepanjangan dan sulit ditemukan penyelesaiannya. Tuntutan pemisahan daerah biasanya muncul karena ketidakmampuan dalam menyelesaikan kekacauan politik seperti pada isu pembentukan Provinsi Sulawesi Timur dan proposal pembentukan Provinsi Sumbawa Barat sebagai pemekaran dari Provinsi Nusa Tenggara Barat.

Pada dasarnya, pemekaran daerah merupakan tindakan yang solutif apabila di dalam penerapan konsep otonomi daerah ditujukan kepada pemerataan distibusi pembangunan sosial dan ekonomi. Hanya saja, pemekaran daerah malah hanya menguntungkan beberapa golongan dan kelompok tertentu. Hal tersebut dapat dibuktikan dengan munculnya sekelompok aktor politik, tokoh-tokoh masyarakat tertentu, oknum anggota militer, dan kelompok pemodal yang seolah-olah turut andil di dalam perancangan pemekaran daerah. Dewasa ini, harus diakui bahwa sebagian besar pemekaran daerah di Indonesia bernuansa politik. Isu pemekaran seringkali dijadikan sebagai isu strategis atau komoditas politik dalam menarik simpati sekelompok masyarakat tertentu.

Artikel ini bertujuan untuk 1) menemukenali faktor yang melatarbelakangi tuntutan pembentukan DOB dengan meredistribusi pulau-pulau tertentu di Kabupaten Kepulauan Selayar; 2) mendeskripsikan peran elit politik dalam upaya pemekaran Kabupaten Kepulauan Selayar; dan 3) menganalisis dinamika terkini terkait isu redistriksi wilayah Kabupaten Kepulauan Selayar.

\section{Desentralisasi dan Otonomi Daerah dalam Konteks Politik Lokal}

Isu pemekaran wilayah yang demikian ini pada akhirnya memunculkan berbagai kontroversi di dalam kehidupan sehari-hari masyarakat. Masyarakat terbelah menjadi dua kelompok besar, yaitu mereka yang setuju dengan rencana pemekaran dan mereka yang bertahan dalam status quo. Pasang surut perbedaan pandangan ini akan kembali mengemuka pada momentum perhelatan politik serta kontestasi di Kabupaten Kepulauan Selayar.

Phillip Mawhod dalam Jeddawi ${ }^{5}$ menjelaskan bahwa desentralisasi mengandung makna adanya kewenangan untuk mengelola secara mandiri urusan-urusan

${ }^{5}$ Murtir Jeddawi, Pro Kontra Pemekaran Daerah (Analisis Empiris) (Yogyakarta: Total Media, 2009), h. 78. 
pemerintahan di daerah dan bukan hanya didominasi oleh kewenangan dari pemerintah pusat. Dengan demikian, desentralisasi dapat diartikan sebagai (1) adanya pembentukan suatu daerah otonom yang baru; (2) adanya suatu daerah otonom yang menerima pendelegasian kewenangan dari level pemerintahan yang lebih tinggi; (3) adanya polarisasi kekuasaan yang dilakukan oleh pemerintah pusat, serta (4) kekuasaan tersebut diberikan kepada perangkat-perangkat pemerintahan di wilatah tersebut.

Isu desentralisasi sebenarnya sangat erat kaitanya dengan otonomi daerah. Sehingga dalam konteks pelaksanaan pemerintahan, istilah desentralisasi dan otonomi daerah sering digunakan secara acak. Hal ini tentu saja memungkinkan terjadinya polarisasi konsep yang sangat cair, khususnya di dalam melihat keterkaitan antara otonomi daerah dan desentralisasi kekuasaan dengan politik lokal. Desentralisasi dapat dinterprestasikan ke dalam tiga konsep. Pertama, sebagai delegasi tugas-tugas tertentu kepada lembaga atau organisasi di luar struktur pemerintah. Namun, pemerintah pusat masih menguasai tanggung jawab secara menyeluruh. Kedua, dekonsentrasi, yang lebih mengacu pada pergeseran proses pengambilan keputusan (decision making) dalam sebuah nagara yang sistemnya tersentralisasi. Ketiga, devolusi, berkaitan dengan transfer kekuasaan secara aktual dari tingkat pemerintahan pusat ke tingkat lebih rendah yaitu pemerintahan daerah. ${ }^{6}$

Smith juga turut mengemukakan beberapa hipotesis yang menjelaskan bahwa implementasi dari sistem desentralisasi akan membawa konsekuensi baik namun juga bisa berujung pada konflik lokal jika terjadi pergeseran dari tujuan awal desentralisasi. Percaturan politik dalam konteks otonomi daerah memiliki tujuan yaitu (1) untuk meningkatkan kesejahteraan daerah. Desentralisasi kekuasaan, idealnya bertujuan agar masyarakat dan elit politik dapat mengembangkan potensi daerah sendiri. Desentralisasi dan otonomi daerah saling terkait dalam upaya pencapaian tujuan hakiki, yakni good governance, meningkatkan kemakmuran, dan demokratisasi di tingkat lokal. ${ }^{7}$ (2) pembagian kekuasan secara merata antara rakyat dan penguasa lokal. Pada hakikatnya kehadiran desentralisasi dan otonomi daerah tidak hanya memberikan kesejahteraan kepada elit-elit lokal terutama para politisi. Namun, masyarakat juga harus memiliki

\footnotetext{
${ }^{6}$ Tri Ratnawati, Pemekaran Daerah: Politik Lokal dan Beberapa Isu Terseleksi (Yogyakarta: Pustaka Pelajar, 2009).

${ }^{7}$ Syarif Hidayat (ed.), Kegamangan Otonomi Daerah (Jakarta: Pustaka Quantum, 2004).
} 
kekuasaan signifikan sehingga sistem desentralisasi tidak hanya menjadi proyek bagi elit politik daerah semata.

Kebijakan desentralisasi yang diimplementasikan di Indonesia telah memicu tuntutan pembentukan beberapa daerah otonom baru melalui pemekaran beberapa provinsi, kabupaten, dan kota. Upaya pemekaran dianggap sebagai sebuah inovasi baru yang mengakselerasi pembangunan dan meningkatkan kualitas pelayanan publik serta sebagai bentuk upaya simplifikasi kendali dan pengawasan dari pemerintah. Pada akhirnya, pemerintah daerah akan lebih leluasa dalam mengolah potensi daerah atau rumah tangganya sendiri. Pemekaran daerah merupakan sebuah bentuk ekonomi yang dicirikan oleh adanya persaingan secara sempurna di mana pemerintah dapat mendayagunakan segenap kewenangannya untuk menyediakan pelayan publik yang efisien, mempertahankan tingkat pajak yang rendah, serta menjamin kebebasan setiap individu anggota masyarakat dalam mengekspresikan pandangannya atas pelayanan publik yang diterimanya. ${ }^{8}$

Kontestasi politik lokal seringkali memantik berbagai perdebatan berkaitan dengan peluang-peluang terbentuknya suatu daerah otonomi baru. Hal yang ditawarkan melalui penelitian ini adalah lahirnya pemikiran untuk memekarkan suatu wilayah seringkali tidak sesuai dengan cita-cita luhur dalam mewujudkan kesejahteraan masyarakat. Yang ada hanyalah praktek pembagian kekuasaan dan terus menempatkan masyarakat sebagai obyek dalam pembangunan sosial dan ekonomi.

\section{Komoditas Politik}

Komoditas menurut Marx ${ }^{9}$ dimaknai sebagai barang atau jasa yang dihasilkan dan digunakan untuk diperjualbelikan. Dalam proses komodifikasi, komoditas juga berkaitan dengan proses distribusi, dan konsumsi. Ekstensifikasi terhadap komoditas juga merambah institusi ekonomi dan institusi sosial yang dikonfigurasikan sedemikian rupa sehingga mengalami berbagai bentuk perubahan, khususnya perubahan yang berkaitan dengan nilai.

\footnotetext{
${ }^{8}$ Iqbal Natsir Assidiqi, dkk., "Ironi Pemekaran Wilayah, Buah Simalakama bagi Kedaulatan Negara Kesatuan Republik Indonesia.” Laporan Penelitian. (Yogyakarta: Fakultas Ilmu Sosial dan Politik, Univeristas Gadja Mada, 2014).

${ }^{9}$ David Smith \& Phil Evans, Das Kapital untuk Pemula (Yogjakarta: Resist Book, 2004).
} 
Dalam konteks penelitian ini, komoditas politik dimaknai sebagai suatu entitas tertentu yang memiliki nilai jual dan daya tarik bagi konstituen atau masyarakat. Komoditas politik seringkali berwujud sebagai keinginan atau cita-cita dari suatu masyarakat yang belum tercapai. Sedangkan, elit merujuk pada asumsi teori elit Pareto ${ }^{7}$, yaitu sekelompok kecil orang atau kelompok yang terorganisir dan memiliki kapabilitas yang dibutuhkan sebagai prasyarat hadirnya kekuasaan sosial dan politik. Elit merupakan figure yang memiliki kedudukan yang linear dengan penguasaan sumbersumber daya melalui kapasitas dalam menentukan jalannya kebijakan di dalam masyarakat. Dalam hal ini, elit di dalam masyarakat terdiri dari dua kumpulan, yaitu elit yang memiliki kewenangan formal (governing elite) dan elit yang tidak memiliki kewenangan (nongoverning elite).

\section{Metode Penelitian}

Penelitian ini dijalankan dengan menggunakan desain penelitian kualitatif dan dikembangkan dengan pendekatan studi kasus pada wacana pemekaran Kabupaten Kepulauan Selayar (case study). Dengan demikian, analisis mengenai latar belakang dan peran masing-masing aktor dapat dilakukan secara lebih spesifik. ${ }^{10}$ Seterusnya, isu pemekaran yang dijadikan komoditas politik yang dipraktekkan oleh elit-elit politik lokal di Kabupaten Kepulauan Selayar juga dapat ditelurusi secara lebih mendalam.

Pengumpulan data dijalankan melalui beberapa teknik pengumpulan data, yaitu dengan menggunakan teknik observasi, wawancara mendalam (in-depth interview) dan teknik dokumentasi. Pengambilan sampel dilakukan berdasarkan metode nonprobability sampling (purposive sampling), di mana informan yang dipilih berdasarkan pertimbangan-pertimbangan tertentu yang dianggap mampu memberikan informasi penting yang berkenaan dengan fenomena yang diteliti.

Setelah pengumpulan data selesai dijalankan, data dianalisis mengan menggunakan teknik analisis data dengan tiga tahapan, yaitu data reduction dengan melakukan pemilahan 11 atas data yang berkenaan dengan penelitian, data display

\footnotetext{
${ }^{10}$ John W. Creswell, Research Design: Pendekatan Kualitatif, Kuantitatif, dan Mixed, Edisi Ketiga (Yogyakarta: Pustaka Pelajar, 2010).
} 
dengan menayangkan data-data secara lebih komprehensif, dan conclusion drowing/verification untuk memastikan kredibilitas data yang telah diperoleh. ${ }^{11}$

\section{Faktor-Faktor yang Melatarbelakangi Lahirnya Tuntutan Pemekaran}

Dari penelitian yang telah dilakukan, diketahui bahwa terdapat beberapa faktor yang menjadi latar belakang lahirnya tuntutan pemekaran 5 kecamatan kepulauan di Kabupaten Kepulauan Selayar, diantaranya adalah sebagai berikut:

\section{Kondisi Geografis Yang Sangat Luas}

Secara geografis, wilayah Kabupaten Kepulauan Selayar terdiri dari pulau-pulau dengan jumlah 11 kecamatan. Dalam wawancara yang dilakukan penulis dengan bapak Dg Mangitung, salah satu politisi yang merupakan pihak terkait dalam isu pemekaran pada 6 Januari 2021 menjelaskan bahwa "Jarak tempuh masyarakat yang berada di wilayah 5 kecamatan kepulauan dalam mengakses pelayanan publik di ibukota kabupaten sangatlah jauh dan membutuhkan waktu yang sangat lama. Sehingga dengan memperpendek rentang kendali melalui usulan pemekaran daerah, akses pelayanan masyarakat secara lebih baik."12

Jarak ke 5 kecamatan kepulauan memanglah sangat jauh dan membuat masyarakat setempat sangat sulit mendapatkan akses pelayanan dari ibukota kabupaten. Bahkan, salah satu kecamatan yaitu Kecamatan Passilambena dengan jarak \pm 193 km ${ }^{13}$ dari ibukota kabupaten lebih memilih melakukan aktivitas ekonomi dan berobat ke rumah sakit di Kota Kupang, Prov. NTT. Hal ini disebabkan faktor jarak yang sangat jauh, dimana jarak kecamatan Passilambena dari Kota Kupang bisa diakses hanya 5-6 jam dengan pelayaran sedangkan jarak tempuh ke ibukota kabupaten bisa memakan waktu satu hari satu malam. Hal ini kemudian dibenarkan oleh salah satu anggota Dewan Perwakilan Rakyat Daerah (DPRD) Prov. Sulawesi Selatan, Ady Ansar, dalam wawancara yang dilakukan penulis pada tanggal 12 Januari 2021.

\footnotetext{
${ }^{11}$ Sugiyono, Metode Penelitian Kualitatif Kuantitatif dan R\&D (Bandung: Alfabeta, 2012).

${ }^{12}$ H.Dg Mangitung, Politisi, wawancara , 6 Januari 2021

${ }^{13}$ Irfan Wahab, "5 Kecamatan di Selayar Bergabung Minta Pemekaran" dalam https:/gosulsel.com/2016/07/06/5-kecamatan-di-selayar-bergabung-minta-pemekaran-kabupaten/ diakses 20 Februari 2021.
} 
"Secara pribadi saya sangat mendukung rencana pemekaran 5 kecamatan kepulauan dikarenakan Kabupaten Kepulauan Selayar secara geografis dibagi menjadi dua kelompok yaitu wilayah daratan dan wilayah kepulauan. Kalau kita melihat rentang kendali atau jarak dari ibukota kabupaten itu sangat jauh dan butuh waktu yang lama dan berhari-hari untuk bisa sampai ke ibukota kabupaten. Sehingga fungsi pemerintahan, baik dari pelayanan, pemberdayaan, maupun pengawasan tidak bisa dilakukan secara optimal. Hal ini terlihat dari kondisi di wilayah kepulauan yang masih belum bisa memenuhi kebutuhan dasar seperti air bersih dibeberapa pulau khususnya di Kecamatan Taka Bonerate dan Passilambena.". ${ }^{14}$

Dari hasil wawancara di atas, penulis menyimpulkan bahwa esensi pemekaran adalah untuk memperpendek rentang kendali yang bertujuan agar tercipta pemerataan pembangunan serta kesejahteraan. Pembangunan yang lebih merata akan membuka akses masyarakat dalam memperoleh pelayanan publik bisa berjalan secara efektif dan efesien.

\section{Keinginan Peningkatan Perekonomian Wilayah Kepulauan}

Kabupaten Kepulauan Takabonerate merupakan nama kabupaten yang akan diusulkan dalam rencana pemekaran pada 5 kecamatan kepulauan di Kabupaten Kepulauan Selayar. Daerah ini dianugerahi sumber daya alam yang kaya dan sangat potensial dan diyakini lebih menyejahterakan masyarakatnya, khususnya pada sektor industri perikanan, pertanian, dan pariwisata. Sektor pariwisata akan menjadi sektor andalan dan memiliki potensi ekonomi yang sangat besar dan diyakini memberikan dampak bagi masyarakat, khususnya di sekitar kawasan Taman Nasional Taka Bonerate. Hal ini dikarenakan Taman Nasional Taka Bonerate adalah ekosistem laut dengan kawasan atol yang sangat besar, bahkan menjadi yang terbesar ketiga di dunia.

Selain itu, yang menjadi pertimbangan lahirnya tuntutan pemekaran ini ialah banyaknya lulusan perguruan tinggi atau sarjana di daerah kepulauan. Namun minimnya ketersediaan lapangan pekerjaan di wilayah kepulauan membuat hal tersebut menyumbang 13 angka pengangguran yang sangat tinggi di daerah kepulauan. Berdasarkan hasil wawancara penulis dengan beberapa pihak baik yang menyatakan setuju maupun yang kontra terhadap isu pembentukan Kabupaten Kepulauan Takabonerate di Kabupaten Kepulauan Selayar, kedua pihak meyakini bahwa

\footnotetext{
${ }^{14}$ Ady Ansar, Anggota DPRD Prov. Sulawesi Selatan, wawancara, 12 Januari 2021.
} 
pembentukan daerah otonom baru akan berdampak pada penyerapan tenaga kerja di berbagai sektor khususnya distribusi kekuasaan di bidang pemerintahan.

Oleh karena itu, penulis menarik kesimpulan bahwa dengan adanya pemberian kewenangan yang luas yang dituangkan dalam kebijakan pemekaran, maka masyarakat di 5 kecamatan kepulauan akan mampu melakukan perbaikan derajat pembangunan sosial dan ekonomi daerah berbasiskan sumber daya lokal dan mempercepat pertumbuhan ekonomi penduduk.

\section{Perbedaan Identitas}

Perbedaan identitas dengan adanya kategorisasi antara entitas 'To Pulo' dan entitas 'To Daratan.” juga menjadi salah satu alasan munculnya tuntutan pemekaran di Kabupaten Kepulauan Selayar. Hanya saja, pembedaan ini lebih kepada pembedaan berdasarkan situasi geografis ${ }^{15}$ yang disertai dengan sedikit sentimen bernuansa hubungan sosial yang mengalami polarisasi. To Pulo dilekatkan sebagai sebutan bagi masyarakat yang tinggal di wilayah 5 kecamatan kepulauan sedangkan To Daratan merupakan julukan bagi masyarakat yang tinggal di Pulau Selayar. Hasil wawancara penulis dengan Ketua Himpunan Pelajar Mahasiswa Kepulauan Selayar (HPMKS) pada tanggal 7 Januari 2021 menjelaskan bahwa:

"Memang benar bahwa salah satu yang melatarbelakangi lahirnya tuntutan pemekaran di Kabupaten Kepulauan Selayar adalah adanya diskriminasi antara masyarakat To Pulo dengan To Daratan. To Pulo di masa lalu merupakan kelompok yang terpinggirkan dalam konteks akses pendidikan. Sumberdaya manusia yang lemah dan infrastruktur yang tidak memadai. Hal ini terjadi karena jumlah orang To Pulo yang bertugas di ibukota kabupaten yang masih sedikit. Kategorisasi ini sering sekali nampak ketika To Pulo dan To Daratan bertemu dalam suatu arena kontestasi apapun seperti contoh kecilnya pertandingan sepak bola dan bahkan dalam ranah persaingan jabatan di organisasi daerah yaitu Gerakan Mahasiswa Pelajar Tanadoang (GEMPITA)."16

${ }^{15}$ Abu Bakar, "Disorientasi Politik dan Peran Intermediary Kelas Menengah To Pulo: Politik Lokal di Kepulauan Selayar Pasca Orde Baru” dalam Jurnal Ilmu Sosial dan Ilmu Politik, Vol.18, No. 3 (2015), h 226-238.

${ }^{16}$ Sulfandi Adriawan, Ketua Himpunan Pelajar Mahasiswa Kepulauan Selayar (HPMKS), wawancara, 7 Januari 2021 


\section{Motif Pemburu Rente dari Para Elit}

Dari analisis The Jawa Post Institute of Pro Otonomi (2008) pemekaran daerah tidaklah sepenuhnya didasarkan pada peningkatan pelayanan publik, akan tetapi motifnya lebih kepada pertimbangan kepentingan elit nasional dan elit lokal. Hal ini pula yang menjadi alasan pihak-pihak kontra yang menganggap bahwa usulan pemekaran 5 kecamatan kepulauan di Kabupaten Kepulauan Selayar lebih banyak didasari kepentingan politik semata. Hasil wawancara penulis dengan salah satu anggota DPRD Kabupaten Kepulauan Selayar pada tanggal 1 Januari 2021 ketika dimintai pandangan terhadap isu pemekaran 5 kecamatan kepulauan menyatakan bahwa:

"Menurut saya, isu pemekaran 5 kecamatan kepulauan merupakan kegiatan politik praktis yang sebenarnya hanya dijadikan momen dan kepentingan politik oleh kelompok tertentu. Tidak ada dorongan atau kehendak dari masyarakat 5 kecamatan pulau untuk mekar." 17

Dari hasil pengamatan penulis di Pulau Kayuadi, Kecamatan Taka Bonerate yang menjadi salah satu wilayah yang akan dimekarkan diketahui bahwa, ternyata banyak masyarakat pulau yang tidak mengetahui rencana pemekaran tersebut. Padahal idealnya rencana pemekaran suatu wilayah berasal dari aspirasi masyarakat. Selama ini isu pemekaran kebanyakan hanya bergulir dikalangan-kalangan tertentu seperti elit-elit politik, birokrat, kelompok terpelajar terutama mahasiswa yang tergabung dalam sebuah organisasi yang katanya menjadi cikal bakal awal munculnya ide pemekaran yaitu Himpunan Pelajar Mahasiswa Kepulauan Selayar (HPMKS).

Hal ini kemudian diperkuat dari beberapa informasi yang penulis dapatkan melalui hasil wawancara penulis dengan seorang tokoh masyarakat pada tanggal 27 Januari 2021 tentang motif yang menjadi alasan munculnya tuntutan pemekaran di Kabupaten Kepulauan Selayar, ia menjelaskan bahwa; 15 tuntutan pemekaran ini hanya diinisiasi oleh elit-elit tertentu tanpa adanya pelibatan masyarakat. Dilihat dari perjalanan isu pemekaran ini, kebanyakan pihak-pihak yang terlibat di dalam upaya pemekaran didasari motif kepentingan politik dan upaya mencari popularitas agar dilirik oleh pejabat-pejabat di pemerintah daerah. Hal ini juga diperkuat dalam beberapa kasus, dimana pihak yang dulunya terlibat aktif dalam upaya pemekaran setelah menduduki

\footnotetext{
${ }^{17}$ Anonim, Anggota DPRD Kabupaten Kepulauan Selayar, wawancara, 1 Januari 2021.
} 
posisi strategis tertentu di birokrasi seakan tidak perduli lagi dan tidak memiliki komitmen untuk melanjutkan perjuangan pemekaran. ${ }^{18}$

\section{Peran Elit Politik Lokal dalam Rencana Pemekaran}

Peran elit politik dalam memperjuangkan pemekaran tentunya berkaitan dengan apa yang akan didapatkan oleh para elite bilamana tahapan pemekaran ini dapat berjalan dan daerah otonom baru dapat terbentuk. Tentunya, hal tersebut tidak terlepas dari sekian banyak pengorbanan yang telah dilakukan oleh elit dalam memperjuangkan pemekaran wilyaha tersebut.

Dalam konteks penelitian ini, usulan pemekaran di Kabupaten Kepulauan Selayar tidak terlepas dari peran dari berbagai pihak baik dari elit pemerintah maupun elit non-pemerintah. Berdasarkan hasil pengamatan dari penulis, usulan pemekaran di Kabupaten Kepulauan Selayar lebih banyak didominasi oleh peran dari elit nonpemerintah seperti politisi, mahasiswa kepulauan atau kelas menengah To Pulo dan tokoh masyarakat. Namun, tidak bisa dipungkiri bahwa rencana pemekaran ini juga melibatkan peran dari elit politik formal yang duduk sebagai anggota legislatif (DPRD Kab. Kepulauan Selayar). Sebenarnya, peran dari elit pemerintah juga ada namun elitelit pemerintah tersebut tidak berani menampakkan diri secara frontal sebagai pihak yang pro akan rencana pemekaran dikarenakan pertimbangan kepentingan politik..

Upaya pertama yang dilakukan elit-elit politik lokal di Kabupaten Kepulauan Selayar adalah dengan membentuk organisasi perkumpulan mahasiswa asal 5 kecamatan di kepulauan yakni HPMKS pada tanggal 18 Mei 2003 di Kota Makassar. Pendirian HPMKS dimotori oleh kalangan tua atau 16 tokoh masyarakat yang tinggal di Makassar dan kalangan muda (mahasiswa asal kepulauan yang kuliah di Makassar). Pendiri HPMKS dari kalangan tua yaitu, Drs. Syahrir Wahab,MM (eks Bupati Selayar) yang kala itu masih menjabat sebagai Sekretars Daerah Kabupaten Jeneponto, H.Daeng Mangitung, Saharuddin, S.Pd.,M.Pd., Drs. Muhtar, MM, Drs. Andi Azis, Ahmad Mangga', Ir. Wajar, Asri Muchtar, H. Burhan Tayyeb, Yusuf Tuan Baso, Apriadi, Drs. Syukur Dg. Manappa', dan Gunawan Muchtar. Sedangkan dari kalangan muda yaitu,

\footnotetext{
${ }^{18}$ Anonim, Tokoh Masyarakat, wawancara, 27 Januari 2021.
} 
Muhammad Roslang mahasiswa UNM, Hasimuddin dan Nur Amin Arsyad, masingmasing merupakan mahasiswa IAIN Alauddin. ${ }^{19}$

Pendirian HPMKS melahirkan sebuah kontrak politik yang salah satunya ialah percepatan pembangunan kepulauan yang seyogyanya terekspresi real dalam upaya advokasi masyarakat HPMKS dan masyarakat kepulauan dalam mendesak Pemerintah Daerah Kabupaten Kepulauan Selayar. Upaya tersebut diorientasikan dalam aksi nyata memperjuangkan 5 kecamatan kepulauan menjadi sebuah kabupaten atau dimekarkan.

Dalam merealisasikan rencana pemekaran tersebut, HPMKS mempunyai peran yang signifikan dalam mendorong masyarakat kepulauan untuk menggolkan Syahrir Wahab sebagai Bupati Kepulauan Selayar pada Pemilukada tahun 2005. Sehingga proses pemekaran 5 kecamatan kepulauan bisa berhasil dengan adanya kekuatan politik dari orang pulau yang menduduki pucuk pimpinan di Kabupaten Kepulauan Selayar.

Pada tahun 2016, peran elit-elit lokal juga terlihat melalui hadirnya elemenelemen masyarakat dari tokoh masyarakat terutama tokoh pemuda kepulauan yang menyuarakan kembali tuntutan pemekaran dengan melakukan demonstrasi di Kota Makassar. Peran elit-elit politik lokal di Kabupaten Kepulauan Selayar juga terlihat ketika adanya pembentukan Forum Percepatan Pemekaran Kabupaten Kepulauan Takabonerate (FP2KT) pada tahun 2017 melalui sebuah deklarasi yang berlokasi di kampus Universitas Muhammadiyah Makassar (UNISMUH) yang dihadiri oleh elit-elit politik kepulauan selayar dan mahasiswa yang sedang berkuliah di Makassar. Deklarasi tersebut dihadiri salah satu anggota DPRD Kabupaten Kepulauan Selayar yaitu H. Daeng Mangitung, dan Abdul Gani pasca Pilkada. Selain itu, deklarasi dihadiri juga banyak tokoh masyarakat yang sangat mendukung rencana 17 pemekaran ini seperti Andi Asling, sekarang menjabat sebagai Camat di Kecamatan Taka Bonerate. Deklarasi ini menghasilkan sebuah Forum yang akan mengupayakan percepatan pemekaran dengan ketua pertama yaitu Tahir yang kemudian menjabat sebagai Ketua Badan Pengawasan Pemilu (Bawaslu) Kabupaten Kepulauan Selayar.

Pada dasarnya, setiap elit yang berperan dalam upaya pemekaran di Kabupaten Kepulauan Selayar memiliki motif kepentingan masing-masing. Ada yang betul-betul ikut berjuang sebagai upaya untuk mewujudkan tujuan mulia yaitu kesejahteraan

\footnotetext{
${ }^{19}$ Muh. Yacub \& Nur Amin Arsyad, Himpunan Pelajar Mahasiswa Kepulauan Selayar Dalam Sejarah dan Pemikiran (Makassar: Bambu Press, 2015).
} 
masyarakat kepulauan. Namun, tidak bisa dipungkiri motif kepentingan berupa kekuasaan atau kepentingan politik lain menjadi alasan yang kuat bagi elit-elit tertentu jika pemekaran ini bisa terealisasikan.

\section{Dinamika Wacana Pemekaran Kabupaten Kepulauan Selayar}

Isu pemekaran 5 kecamatan kepulauan di Kabupaten Kepulauan Selayar telah lama bergulir sejak berpuluh-puluh tahun lamanya. Ide tentang pemekaran muncul pasca jatuhnya rezim Orde Baru yang didahului dengan terbentuknya kesadaran dari kelompok menengah To Pulo untuk mengambil ruang dan ikut andil dalam kontestasi politik lokal di Kepualaun Selayar. Kesadaran tersebut muncul dari adanya marginalisasi kepulauan yang dipengaruhi kondisi geografis Kabupaten Kepulauan Selayar. Keikutsertaan entitas To Pulo pada kontestasi politik di Kepulaun Selayar kemudian diaktualisasikan dengan didirikannya sebuah organisasi kemahasiswaan yang menaungi mahasiswa asal 5 kecamatan di kepulauan pada 18 Mei 2013.

Hasrat mahasiswa kepulauan mendirikan HPMKS juga didasari oleh kesadaran primordial akan marginalisasi kepulauan. Masyarakat To Pulo merasakan adanya ketidakadilan Pemerintah Kabupaten Kepulauan Selayar saat itu. Salah satu penyebab kuat kepulaun kurang tersentuh oleh kebijakan pembangunan pemerintah karena masih sedikit To Pulo yang menduduki jabatan strategis di kabupaten.

Marginalisasi yang menyandera masyarakat kepulauan membuat kesadaran mereka muncul dan bermuara pada konvensi politik To Pulo yang dilaksanakan pada saresehan To Pulo di Balai Penataran Guru (BPG) yang melahirkan beberapa rekomendasi yaitu (1) Menyepakati satu nama tokoh pulau untuk bertarung pada Pilkada 2005, alhasil nama Syahrir Wahab yang disepakati dan terpilih menjadi bupati, (2) membawa 8 anggota elit asal 18 kepulauan untuk duduk di parlemen lokal, serta (3) membentuk komite khusus yang bertugas melakukan percepatan pembangunan. ${ }^{20}$

Terpilihnya Syahrir Wahab sebagaimana yang telah dicita-citakan, yaitu representasi dari To Pulo diharapkan menjadi titik terang dan modal kekuatan politik yang besar akan terealisasinya isu pemekaran 5 kecamatan kepulauan. Namun, selama masa jabatannya dalam kurung waktu dua periode tidak terlihat sama sekali upaya yang

\footnotetext{
${ }^{20} \mathrm{Abu}$ Bakar, Loc.Cit.
} 
mengarah pada pemekaran. Pihak-pihak yang terlibat dalam perjuangan pemekaran juga tidak memiliki komitmen yang tinggi dalam mendesak Pemerintah Daerah untuk menyetujui tuntutan pemekaran sebagai kontrak politik yang telah disetujui bersama.

Dari hasil wawancara penulis dengan salah salah satu informan kunci tentang alasan mengapa tidak adanya upaya ke arah pemekaran pasca terpilihnya Syahrir Wahab, diketahui bahwa alasan yang melatarbelakangi permasalahan tersebut ialah gerakan politik identitas yang dipercaya akan mengawal isu pemekaran ini sama sekali tidak bersifat ideologis dan mengakar. Komitmen pihak-pihak di dalamnya sangatlah lemah dan lebih disibukkan dengan hal-hal yang sifatnya pragmatis serta untuk kepentingan sesaat, sehingga mimpi masa lalu berupa pemekaran tidak diadvokasi secara serius meskipun saat itu To Pulo memiliki kesempatan yang sangat luas untuk melakukan pemekaran.

Mimpi akan terwujudnya pemekaran 5 kecamatan kepulauan sebenarnya semakin jauh dari kata berhasil. Hal tersebut merupakan implikasi dari lahirnya PP No. 59/2008. ${ }^{21}$ Hal ini justru semakin ironis karena terjadi di masa kepemimpinan seorang figur yang selama ini dianggap merepresentasikan masyakarat 'To Pulo' pada pentas politik lokal.

Lahirnya PP No. 78 tahun $2007^{22}$ yang merupakan perbaikan dan atau penyempurnaan dari PP No. 129 tahun 1999 juga merupakan faktor penghambat dalam upaya pemekaran di Kabupaten Kepulauan Selayar. Kehadiran PP No. 78 tahun 2007 dimaksudkan untuk semakin memperketat syarat-syarat pemekaran daerah. Hal ini tentunya menjadi permasalahan serius yang harus dihadapi elit-elit yang mendukung rencana pemekaran di Kabupaten Kepulauan Selayar. Tidak selesai pada tataran belum terpenuhinya syarat administratif berupa persetujuan dari Bupati dan DPRD, kini rencana pemekaran juga harus dihadapkan pada kenyataan bahwa salah satu syarat yang harus dipenuhi berupa syarat fisik kewilayahan yang mengharuskan adanya minimal 7 kecamatan dalam satu kabupaten pemekaran.

\footnotetext{
${ }^{21}$ Pemerintah RI, "Peraturan Pemerintah Republik Indonesia Nomor 59 Tahun 2008 Perubahan Nama Kabupaten Selayar Menjadi Kabupaten Kepulauan Selayar Provinsi Sulawesi Selatan" dalam https://peraturan.bpk.go.id/Home/Details/4875/pp-no-59-tahun-2008\#: :text=PP\%20No.\%2059\%20Tahu n\%202008,Sulawesi\%20Selatan\%20\%5BJDIH\%20BPK\%20RI\%5D diakses 1 Februari 2021.

${ }^{22}$ Pemerintah RI, "Peraturan Pemerintah Republik Indonesia Nomor 78 Tahun 2007 tentang tentang Tata Cara Pembentukan Penghapusan Dan Penggabungan Daerah" dalam https://peraturan.bpk.go.id/Home/Details/4806/pp-no-78-tahun-2007 diakses 1 Februari 2021.
} 
Tuntutan pemekaran menjadi isu yang sangat hangat diperbincangkan pasca pelaksanaan Pilkada yang berhasil dimenangkan oleh pasangan Basli-Zainuddin setelah berhasil unggul dari pasangan Aji-Gani yang notabenenya merupakan anak/keluarga dari bupati periode sebelumnya, yakni Syahrir Wahab. Kemunculan kembali pemekaran sebagai isu hangat ditandai dengan dilaksanakannya sebuah deklarasi yang menghasilkan dibentuknya sebuah Forum Percepatan Pemekaran Kabupaten Kepulauan Taka Bonerate (FP2KT) pada tahun 2017. Kegiatan tersebut banyak menuai tanggapan negatif dan diklaim sebagai wujud rasa kekecewaan dan sakit hatri atas kekalahan AjiGani pada pelaksanaan Pilkada sebelumnya.

Pembentukan FP2KT tidak dibekali dengan persiapan yang matang. Bedasarkan hasil wawancara dengan beberapa pihak yang terlibat dan menjadi anggota dalam forum tersebut diketahui bahwa banyak di antara mereka tidak mengetahui adanya perubahan peraturan terutama dalam syarat fisik kewilayahan dengan minimal 7 kecamatan dalam satu kabupaten pemekaran. Jika ditinjau dari syarat tersebut isu pemekaran 5 kecamatan kepulauan tidaklah memenuhi syarat pemekaran daerah. Menurut penulis hal ini semakin memperjelas bahwa ada motif lain dalam pembentukan FP2KT.

Sampai saat ini tidak ada titik terang dari isu pemekaran 5 kecamatan kepulauan di Kabupaten Kepulauan Selayar. Apalagi berbagai pihak yang mendukung pemekaran setelah mendapatkan jabatan strategis di ranah politik dan birokrasi sebagai Aparatur Sipil Negara (ASN) sudah tidak memperlihatkan komitmen yang kuat ke arah pemekaran. Sampai sekarang saat ini, isu pemekaran 5 kecamatan kepulauan mulai surut kembali dalam mewarnai dinamika politik lokal di Kabupaten Kepulauan Selayar namun tetap menjadi perbincangan dikalangan elit-elit tertentu.

\section{Penutup}

Berangkat dari permbahasan yang telah diuraikan, penelitian ini menyimpulkan bahwa kondisi geografis yang sangat luas, ketimpangan dalam pembangunan sosial dan ekonomi, permasalahan identitas budaya yang berbeda serta adanya motif pemburu rente di kalangan elit lokal adalah faktor-faktor yang telah melatarbelakangi lahirnya tuntutan pemekaran 5 kecamatan kepulauan di Kabupaten Kepulauan Selayar.

Di beberapa kasus upaya pemekaran daerah di Indonesia, gagasan tersebut biasanya dikemukakan oleh sekelompok elite politik yang didasari oleh tendensi politik 
dan perebutan kekuasaan. Wacana pemekaran 5 kecamatan kepulauan di Kabupaten Kepulauan Selayar diketahui banyak melibatkan peran elit-elit politik lokal baik elit di eksekutif (governing elit) maupun elit yang tidak berada dalam lingkaran kekuasaan (non-governing elit). Seperti para politisi yang pernah berkuasa di masa lalu, ataupun sekelompok orang yang menginginkan popularitas dan sumber daya yang ada di daerah kepulauan. Meskipun tuntutan ini merefleksikan keinginan masyarakat, akan tetapi penelitian ini menemukan bahwa pada hakikatnya para elit politik lokallah yang memang menegaskan isu pemekaran ini untuk segera direalisasikan. Hal ini nampak dari berbagai upaya yang telah dilakukan para elit politik untuk merealisasikan pemekaran yaitu pembentukan sebuah organisasi mahasiswa yang bertujuan untuk mengawal pemekaran dan pembentukan sebuah forum untuk percepatan pemekaran.

Di dalam perkembangannya, isu pemekaran ini memunculkan berbagai pertentangan di khalayak dan politisi karena sering dianggap sebagai kegiatan politik praktis oleh kelompok tertentu yang mengatasnamakan kepentingan masyarakat kepulauan. Dalam perjalananya isu pemekaran ini mendapatkan berbagai tantangan dalam pemenuhan syarat terbentuknya sebuah daerah pemekaran yang telah digariskan melalui PP No. 78/2007. Salah satu dari beberapa tantangan yang dihadapi di antaranya adalah tidak terpenuhinya syarat administratif berupa persetujuan dari Bupati Kepulauan Selayar dan syarat fisik minimal 7 kecamatan dalam satu kabupaten pemekaran. Hal tersebutlah yang menyebabkan mengapa isu pemekaran 5 kecamatan kepulauan di Kabupaten Kepulauan Selayar belum terealisasi walaupun telah bergulir puluhan tahun.

\section{DAFTAR PUSTAKA}

Assidiqi, Iqbal Natsir, dkk. "Ironi Pemekaran Wilayah, Buah Simalakama bagi Kedaulatan Negara Kesatuan Republik Indonesia." Laporan Penelitian. Yogyakarta: Fakultas Ilmu Sosial dan Politik, Univeristas Gadja Mada, 2014.

Bakar, Abu. "Disorientasi Politik dan Peran Intermediary Kelas Menengah To Pulo: Politik Lokal di Kepulauan Selayar Pasca Orde Baru" dalam Jurnal Ilmu Sosial dan Ilmu Politik, Vol.18, No. 3 (2015), h 226-238.

Creswell, John W. Research Design: Pendekatan Kualitatif, Kuantitatif, dan Mixed, Edisi Ketiga. Yogyakarta: Pustaka Pelajar, 2010. 
Edmonds-Poli, Emily \& Eduardo J. Gómez. "The Politics of Decentralization and Municipal Autonomy in Mexico and India" dalam Paper dipresentasikan pada the Annual Meeting of the American Political Science Association, San Francisco, 29 Agustus-2 September (2001).

Hidayat, Syarif (ed.). Kegamangan Otonomi Daerah. Jakarta: Pustaka Quantum, 2004.

Hoessein, Bhenyamin. "Penyempurnaan UU No.22 Tahun 1999 Menurut Konsepsi Ootonomi Daerah Hasil Amandemen UUD 1945" dalam Makalah Untuk Seminar "Pembangunan Hukum Nasional VIII" yang diselnggarakan oleh BPHN Departemen Kehakiman dan HAM , Denpasar, 14-18 Juli (2003).

Jeddawi, Murtir. Pro Kontra Pemekaran Daerah (Analisis Empiris). Yogyakarta: Total Media, 2009.

Ratnawati, Tri. Pemekaran Daerah: Politik Lokal dan Beberapa Isu Terseleksi. Yogyakarta: Pustaka Pelajar, 2009.

Smith, David \& Phil Evans. Das Kapital untuk Pemula. Yogjakarta: Resist Book, 2004.

Sugiyono. Metode Penelitian Kualitatif Kuantitatif dan R\&D. Bandung: Alfabeta, 2012.

Yacub, Muh. \& Nur Amin Arsyad. Himpunan Pelajar Mahasiswa Kepulauan Selayar Dalam Sejarah dan Pemikiran. Makassar: Bambu Press, 2015.

\section{Website}

Kemendagri. "Wilayah Indonesia Pasca Mengalami Pemekaran" dalam www.kemendagri.go.id. diakses 28 Maret 2021.

Pemerintah RI. "Peraturan Pemerintah No. 129 Tahun 2000 tentang Persyaratan Pembentukan Dan Kriteria Pemekaran, Penghapusan, Dan Penggabungan Daerah" dalam https://peraturan.bpk.go.id/Home/Details/53948/pp-no-129tahun-2000 diakses 1 Februari 2021.

Pemerintah RI. "Peraturan Pemerintah Republik Indonesia Nomor 59 Tahun 2008 Perubahan Nama Kabupaten Selayar Menjadi Kabupaten Kepulauan Selayar Provinsi Sulawesi Selatan" dalam https://peraturan.bpk.go.id/Home/ Details/4875/pp-no-59-tahun-2008\#: :text=PP\%20No.\%2059\%20Tahun\%2020 08,Sulawesi\%20Selatan\%20\%5BJDIH\%20BPK\%20RI\%5D diakses 1 Februari 2021.

Pemerintah RI. "Peraturan Pemerintah Republik Indonesia Nomor 78 Tahun 2007 tentang tentang Tata Cara Pembentukan Penghapusan Dan Penggabungan Daerah" dalam https://peraturan.bpk.go.id/Home/Details/4806/pp-no-78-tahun2007 diakses 1 Februari 2021. 
Wahab, Irfan. "5 Kecamatan di Selayar Bergabung Minta Pemekaran" dalam https://gosulsel.com/2016/07/06/5-kecamatan-di-selayar-bergabung-mintapemekaran-kabupaten/ diakses 20 Februari 2021.

\section{Wawancara}

Ady Ansar, Anggota DPRD Prov. Sulawesi Selatan, wawancara, 12 Januari 2021.

Anonim, Anggota DPRD Kabupaten Kepulauan Selayar, wawancara, 1 Januari 2021.

Anonim, Tokoh masyarakat, wawancara, 27 Januari 2021.

H.Dg Mangitung, Politisi, wawancara , 6 Januari 2021

Sulfandi Adriawan, Ketua Himpunan Pelajar Mahasiswa Kepulauan Selayar (HPMKS), wawancara, 7 Januari 2021 